\title{
Burkitt's neurolymphomatosis of the trigeminal nerve
}

\author{
Isaac Phang, ${ }^{1}$ Anna Craig-Mcquaide, ${ }^{1}$ Kevin Kinch, ${ }^{2}$ William Taylor ${ }^{1}$
}

${ }^{1}$ Department of Neurosurgery, Institute of Neurological Sciences, Queen Elizabeth University Hospital, Glasgow, UK ${ }^{2}$ Department of Neuropathology, Institute of Neurological Sciences, Queen Elizabeth University Hospital, Glasgow, UK

\section{Correspondence to}

Mr Isaac Phang,

isaacphang@nhs.net

Accepted 29 July 2018

\section{DESCRIPTION}

A 48-year-old woman presented with 8 months of right-sided burning facial pain and 4 weeks of unsteadiness. She had reduced right facial sensation and corneal reflex. She had no pyramidal or cerebellar signs. Examination of the other cranial nerves was unremarkable. She had reduced sensation in all modalities along the left side of her body.

MRI showed a right-sided enhancing cerebellopontine angle lesion indenting the mid-pons contiguous with a thickened trigeminal nerve extending towards Meckel's cave (figure 1A) with subtle enhancement of the vermis and posterior pons. There was also oedema of the pons (figure 1B). Whole-body CT and PET were unremarkable.

A benign pathology such as trigeminal schwannoma or meningioma of the cerebellopontine angle was considered. Therefore, subtotal resection was performed to decompress the pons for symptomatic relief.

Histopathology revealed a malignant infiltrate of large, mitotically active, atypical lymphoid cells, showing a starry-sky pattern (figure 2A). Ki-67 index was nearly $100 \%$, an archetypal feature of Burkitt's lymphoma (figure 2B). Fluorescent in situ hybridisation confirmed the presence of an IGH-MYC translocation.

Burkitt's lymphoma comprised $0.62 \%$ of primary central nervous system lymphoma (PCNSL), which itself comprises 1\%-2\% of all non-Hodgkin's lymphoma. ${ }^{1}$ Cranial nerve lymphoma, other than optic nerve involvement, is extremely rare. ${ }^{2}$ Adjuvant methotrexate and rituximab as per treatment for PCNSL was performed. Autologous bone marrow transplant will be considered if there is good clinical response. The prognosis for Burkitt's lymphoma of the CNS is unknown due to its rarity, but 5 -year survival for PCNSL is $42 \%{ }^{1}$

\section{Learning points}

- The differential diagnosis is a benign pathology such as trigeminal schwannoma or meningioma. However, in view of rapid progression of symptoms of crossed brainstem signs, consider a malignant process.

- In view of brainstem oedema and diffuse enhancement, consider a malignant process in the differential diagnosis.

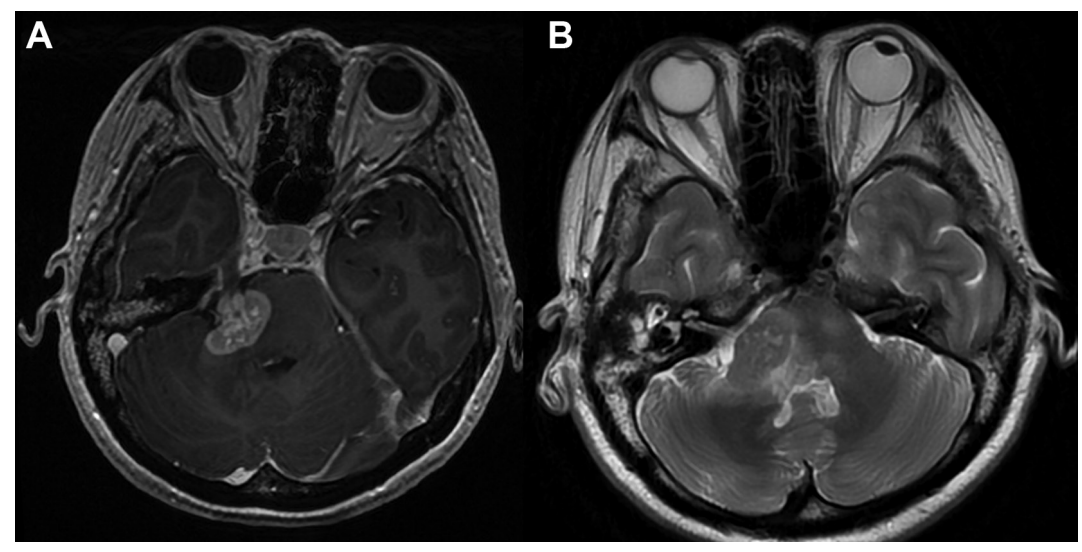

Figure 1 MRI brain. (A) T1-weighted post-gadolinium. (B) T2-weighted image.

Check for updates

(C) BMJ Publishing Group Limited 2018. No commercial re-use. See rights and permissions. Published by BMJ.

\begin{tabular}{|l|}
\hline To cite: Phang I, \\
Craig-Mcquaide A, Kinch K, \\
et al. BMJ Case Rep \\
Published Online First: \\
[please include Day Month \\
Year]. doi:10.1136/bcr-2018- \\
225958
\end{tabular}

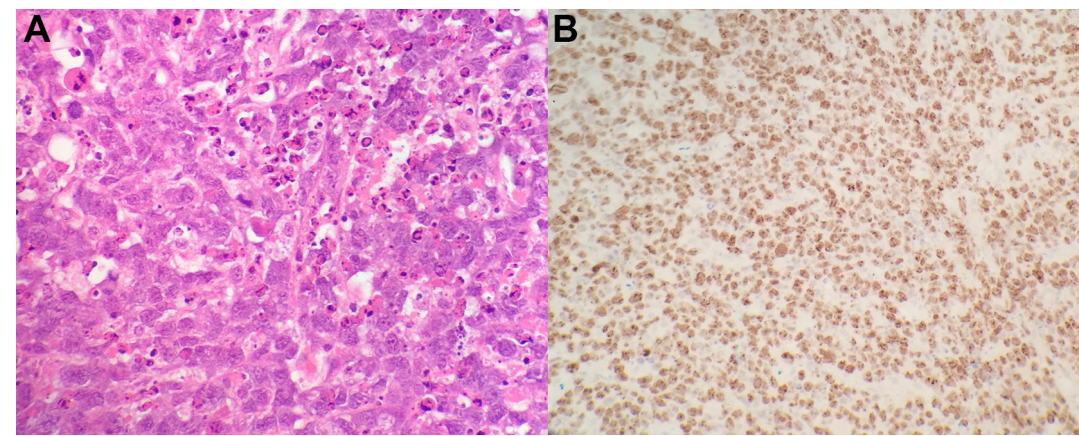

Figure 2 Histopathology. (A) H\&E-stained section. (B) Ki-67 staining. 
Contributors IP drafted the article and did a literature review. AC-M performed a literature review and helped draft the article. KK provided neuropathology input and images. WT approved the submission of the final article.

Funding The authors have not declared a specific grant for this research from any funding agency in the public, commercial or not-for-profit sectors.

Competing interests None declared.

Patient consent Obtained.
Provenance and peer review Not commissioned; externally peer reviewed.

\section{REFERENCES}

1 Chihara D, Fowler NH, Oki Y, et al. Impact of histologic subtypes and treatment modality among patients with primary central nervous system lymphoma: a SEER database analysis. Oncotarget 2018;9:28897-902.

2 Ogiwara T, Horiuchi T, Sekiguchi N, et al. Primary malignant lymphoma of the trigeminal nerve: case report and literature review. World Neurosurg 2015;84:592.e3-7.

Copyright 2018 BMJ Publishing Group. All rights reserved. For permission to reuse any of this content visit

http://group.bmj.com/group/rights-licensing/permissions.

BMJ Case Report Fellows may re-use this article for personal use and teaching without any further permission.

Become a Fellow of BMJ Case Reports today and you can:

- Submit as many cases as you like

- Enjoy fast sympathetic peer review and rapid publication of accepted articles

Access all the published articles

Re-use any of the published material for personal use and teaching without further permission

For information on Institutional Fellowships contact consortiasales@bmjgroup.com

Visit casereports.bmj.com for more articles like this and to become a Fellow 